\title{
Suicide attempts: A contingency analysis
}

\section{Tentativas de suicídio: uma análise de contingências}

\author{
Flávia Caroline FIGEL' \\ Cláudia Lúcia MENEGATTI ${ }^{2}$ \\ Elke do Pilar Nemer PINHEIRO
}

\begin{abstract}
The aim of this study was to understand, from the perspective of behavioral analysis, the possible antecedents and consequences of a suicide attempt for the individual responsible, using reports from patients that were hospitalized in a psychiatric hospital located in Curitiba, Paraná, Brazil, due to their suicide attempts. Three patients that attempted suicide in 2010 took part in this study. Semi-structured interviews were performed, which included questions about the attempt, its antecedents and consequences, and the life history of the patient. Functional analysis showed the presence of risk factors for suicide, as well as reinforcing consequences for the individuals, such as social care only being available after the attempts.
\end{abstract}

Uniterms: Functional analysis; Risk factors for suicide; Suicide attempt.

\section{Resumo}

O objetivo desta pesquisa foi compreender, sob a ótica analítico-comportamental, os possíveis desencadeantes e as consequências para o próprio indivíduo de suas tentativas de suicídio, a partir dos relatos de pacientes que foram internados em um hospital psiquiátrico de Curitiba, Paraná, em decorrência da tentativa. Participaram deste estudo três pacientes que fizeram tentativa de suicídio em 2010 . Foram realizadas entrevistas semi-estruturadas, contendo questões acerca da tentativa, assim como de seus antecedentes e consequentes, além de dados sobre a história de vida a partir da análise funcional. Evidenciou-se a presença de fatores de risco para o suicídio, além de consequências reforçadoras para os indivíduos, como a atenção social, disponibilizada apenas após a realização das tentativas.

Unitermos: Análise funcional; Fatores de risco para o suicídio; Tentativa de suicídio.

Every year, around one million people commit suicide, and each 40 seconds somebody dies for that reason. This value refers to nearly $15 \%$ of all deaths in the world, and as such, is the tenth leading cause of fatalities (Fleischmann, 2009). Furthermore, the estimate of the World Health Organization (WHO) is that, up to the year 2020, approximately 153 million people will die due to suicide, and from 10 to 20 times more individuals will attempt it. This corresponds to one death every 20 seconds, and a suicide attempt once every 2 seconds (Bertolote \& Fleischmann, 2002a).

Therefore, the performance of studies on suicide is of utmost importance because, from a clear understanding of this subject, the development of

\section{$\boldsymbol{\nabla} \boldsymbol{\nabla} \boldsymbol{\nabla}$}

1 Psicóloga. Curitiba, PR, Brasil.

2 Universidade Positivo, Curso de Psicologia. Curitiba, PR, Brasil.

3 Hospital Espírita de Psiquiatria Bom Retiro, Setor de Psicologia. R. Eleonora Muricy Novaes, 171, Jd. Botânico, 82215-320, Curitiba, PR, Brasil. Correspondência para/Correspondence to: E.P.N. PINHEIRO.E-mail: <enemer@terra.com.br>. 
treatment strategies for people who attempt suicide becomes possible. In the present study, based on Applied Behavioral Analysis, the possible functions of this behavior were analyzed from the reports of individuals hospitalized due to a suicide attempt, providing the understanding of the life contingencies of individuals who contributed to this act. Through identifying these contingencies (construed as dependency relationships between behavior and environmental events), future studies may suggested the development of strategies aiming to prevent such risk behavior.

In the literature there are some disagreements about the meaning of suicidal behaviors. Thus, it becomes necessary to make some distinctions between different classes of responses involved, such as suicidal ideation, suicide attempt and actual suicide. According to clinical and epidemiological studies (Mann, Waternaux, Haas \& Malone, 1999), there is the presence of a steep gradient between these behavioral classes. At one extreme is suicidal ideation, which contemplates the ideas, desires and thoughts of being dead. At the other extreme is actual suicide, the consequence of which is the death of the person. Suicide attempts are situated between these two extremes (Turecki, 1999).

A suicide attempt can be defined as an action that presents a threat to life, requiring medical attention, and was committed with the conscious intention of ending one's own life (Meleiro \& Bahls, 2004). The American Psychology Association (APA) defines attempted suicide as self-injurious behavior that was not fatal, with some evidence - that can be explicit or implicit - that the individual intended to die (Jacobs et al., 2003; O'Carroll et al., 1996) The difficulty in assessing and quantifying the intention of dying in these acts must, however, be highlighted (Oliveira, Amâncio \& Sampaio, 2001).

Recent studies have sought to determine what the risk factors for suicide are. Regarding gender, in Brazil as well as the majority of other countries, suicide is two to three times more common in men than in women, however, the opposite occurs in relation to attempts, with them being more frequent in women than in men (Meleiro \&Teng, 2004). Men have also been found to use more lethal methods for suicide attempts or for the achievement of suicide (Dalgalarrondo, 2000; Meleiro

212 \&Teng, 2004).
The presence of a psychiatric disorder is an important factor to be considered regarding suicide rates, suicide attempt rates and suicidal ideation. According to data from the $\mathrm{WHO}$, in $90 \%$ of suicide cases, the individual was suffering from a psychiatric disorder and, in the majority of cases, more than one psychiatric disorder was detected (Prieto \&Tavares, 2005).

With respect to other factors related to suicide, sociologist Émile Durkheim (1897/1951) analyzed it as a social phenomenon, emphasizing factors as causes external to the individual, but not completely ruling out the individual characteristics of each suicide "We may therefore be sure that there are several sorts of suicide which are distinct in quality from one another. But the certainty that these differences exist is not enough; we need to observe them directly and know of what they consist" (Durkheim, 1897/1951, p.277).

From the Behavioral Analysis perspective, Banaco (2001) states that an issue which needs to be discussed about suicide is the fact that the same topography may present different functions, as well as different topographies having the same function. Therefore, considering suicide, its topography becomes more evident; however, from the view of Behavioral Analysis, attention must also be paid to the function of the behavior. The different types of suicidal responses, such as suicide ideation, suicide attempts and actual suicide, present a function that is clearly different in each response. In the case of the suicide attempt, for example, its consequences can be reinforcing, such as sympathy, punishment or contempt.

Sidman (2001) highlights the inability of the individual to meet the social demands, and guilt for not feeling worthy of these relationships as possible causes of suicide. This inability can cause the person to feel like a failure, which occurs when the actions of the individual produce no further positive reinforcement (the addition of something that causes his behavior to continue, that would be success) but, instead, are ignored or punished. Furthermore, some factors must be considered, such as the loss of important sources of reinforcement, as in the case of the death of a close person, or the possibility of being an escape response from situations of physical violence and humiliation (Banaco, 2001).

From the behaviorism perspective, functional behavioral analysis is an instrument that helps in the 
comprehension of the variables related to suicide. According to Matos (1999), to undertake a functional analysis means identifying the adaptive value of a particular behavior, considering the environment aspects and the function of this behavior. Therefore, the purpose of this research is to comprehend the possible antecedents and consequences of the suicide attempt for the individual. From this analysis, hypotheses were produced regarding the contingencies of the life history of these individuals that led them to commit this action.

\section{Method}

The study was approved by the Research Ethics Committee of the Universidade Positivo, protocol no 212/2009, in 12/10/2009, and all participants signed the terms of Free Prior Informed Consent prior to their inclusion in the study.

\section{Participants}

Participants of this study were two women and one man (P1,P2 and P3), aged 52,49 and 36 respectively, hospitalized in a psychiatric hospital in Curitiba (PR), Brazil, due to suicide attempts.

\section{Location}

The study was conducted at the Hospital Espirita de Psiquiatria Bom Retiro (Psychiatric Hospital Bom Retiro), located in Curitiba (PR).

\section{Instruments}

A semi-structured interview script (containing themes concerning the life history of the individual) was formulated, including questions related to the suicidal behavior, the antecedents and the consequences of the suicide attempt.

\section{Data Analysis}

Based on the analysis of the participants' reports, a molar functional analysis was carried out in each case, which analyzed the occurrence of the suicidal behavior in a broader sense related to the life history of the individual, and a molecular analysis illustrated by frames was also performed. In the molecular functional analysis, specific situations in the life of the participants were analyzed, differentiating historical, current and immediate antecedents that contributed to the current suicide attempt.

\section{Results}

Here the information obtained and analyses conducted of the interviews of each of the cases (P1, P2 and P3) is described.

Participant P1 was 52 years of age, married and had three daughters. She had a history of psychiatric hospitalizations - the first of the 12 hospitalizations occurred at age 18. It was in this period that the suicide attempts began (approximately ten attempts, according to her account).

With regard to her familial relationship, P1 stated that the relationships with her husband and daughters were not good, because they were too distant. There was no communication with her husband and she had difficulty in expressing her feelings to him. P1 reported that she had bad thoughts, such as "Stabbing my daughter, decapitating my mother-in-law", and that she felt guilty afterwards. She also stated that the relationship with her mother was bad because it was characterized by frequent punishment, and her mother usually criticized her for everything she did. When visiting her mother, she ended up feeling angry at her because of the excessive criticism and, as a result, practiced avoidance behaviors: "So I'm avoiding going there too" and escape behaviors: "I leave her there cursing, hitting things and l leave...", not to feel bad about what her mother said to her and to avoid the aversiveness of the conflicts. The avoidance behaviors occurred even with telephone contact. When she was a child, P1 reported that she was beaten every day by her mother and, sometimes, by her brothers too. Regarding her father, now deceased, she reported that she felt very angry because he tried to rape her at age 12, and that she had tried to commit suicide several times due to this fact.

In the report of $\mathrm{P} 1$, risk factors for suicide present in her life become evident. There was the presence of a psychiatric disorder that was diagnosed at the hospital, 
where she was hospitalized with Bipolar Affective Disorder, as well as the presentation of suicidal ideation for at least two and a half years, and previous suicide attempts. Furthermore, she reported that she had no friends, relating only to family members, which demonstrates little social support: "Ah, I feel a little bit bad because I wish I had someone to talk to, to unburden..." (Chart 1).

Participant P2 was 49 years of age, married, and had two daughters and a son. P2 received a diagnosis of depression made by a psychiatrist that she consulted about a year prior to the suicide attempt. She had already made other attempts, always by ingestion of medicines.

Concerning her familial relationship, P2 stated that she had relationship difficulties with her husband. According to her, he did not give her attention, did not comprehend that she had depression, did not help with housework or with the children and, furthermore, did not give her affection: "And he is of a surly kind... . Doesn't give any affection, doesn't talk". She also stated that he often shouted at her and abused her. It is possible to hypothesize that, in this relationship, there was much more aversive stimulation than positive reinforcement, since most of her behavior was consequently attached to some sort of punishment. P2 could not tell her husband how she felt, and always "kept everything to herself", avoiding the possible punishments that she could receive if she told him how she felt.

After this suicide attempt, P2 stated that she did not want to try it again, however, also did not know what her reaction would be when she stopped receiving the day-hospital treatment, because she always got sad when returning home. She claimed that one of the reasons for this sadness was the presence of her husband, his shouts and threats: "Because when he is there I don't feel good I get home and feel like going back, it makes me really sad...". Some risk factors for suicide were present in the life of P2, such as a psychiatric disorder (depression diagnosis), as well as the presence of suicide ideation for about a month, and previous suicide attempts (Chart 2).

Participant P3 was 36 years of age, married, and had three children. In his last suicide attempt, he used several methods: blade, knife and scissor. P3 had a history of suicide attempts (did not know exactly how many), and had tried several methods, such as ingestion of medicines and a gun, as well as lying in the middle of a highway. According to his report, the suicide attempts began at the age of 10, lasting until the present moment: "When I was a child, I already tried to kill myself... . Then, at

\section{Chart 1}

Functional analysis of $\mathrm{P} 1$ 's current suicide attempt

\begin{tabular}{|c|c|c|}
\hline Antecedents & Responses & Consequences \\
\hline $\begin{array}{l}\text { Historical } \\
\text { History of sexual abuse perpetrated } \\
\text { by her father and difficulties in the } \\
\text { relationship with him. } \\
\text { Abuse history perpetrated by a } \\
\text { teacher and a boss (abusive } \\
\text { relationships). }\end{array}$ & $\begin{array}{l}\text { Aversive emotional state. } \\
\text { Behavioral passivity and submission. } \\
\text { Beginning of self-injurious behaviors in } \\
\text { late adolescence. } \\
\text { Medication abuse. }\end{array}$ & $\begin{array}{l}\text { Continuity of the paternal abuse. } \\
\text { Lack of coping responses. } \\
\text { Intensification of aversive emotional state. } \\
\text { Behavioral deficits throughout the life history. } \\
\text { Lack of social abilities, such as communication, expression } \\
\text { of feelings and problem solving abilities. Consequent } \\
\text { susceptibility to other abuse. }\end{array}$ \\
\hline Current & Suicide attempts. & Psychiatric hospitalizations. \\
\hline Financial problems - Marital problems. & $\begin{array}{l}\text { Call her mother (to complain). Visit her } \\
\text { mother. }\end{array}$ & $\begin{array}{l}\text { Mother criticizes her and starts verbal conflicts (punishment). } \\
\text { She becomes to avoid calling and visiting her mother. }\end{array}$ \\
\hline $\begin{array}{l}\text { Immediate } \\
\text { Presence of bad thoughts. } \\
\text { Report: "Of stabbing, of decapitating } \\
\text { my mother-in-law", "Because I keep } \\
\text { on thinking, keep, keep, keep, keep } \\
\text { it in my head... it was really bad". }\end{array}$ & $\begin{array}{l}\text { Current suicide attempt } \\
\text { Ingestion of medicine. } \\
\text { Covert behaviors: bad thoughts. } \\
\text { Feelings: anxiety and nervousness. } \\
\text { Was voluntarily hospitalized in a } \\
\text { psychiatric institution. }\end{array}$ & $\begin{array}{l}\text { Her family did not realize that she had ingested the } \\
\text { medicine - absence of reinforcement. } \\
\text { The medicine did not have a lethal effect - absence of } \\
\text { reinforcement. } \\
\text { Physical discomfort, feelings od frustration due to her } \\
\text { underachievement, regret regarding the attempt, } \\
\text { indifference from the hospital's patients - positive } \\
\text { punishment. }\end{array}$ \\
\hline
\end{tabular}


Chart 2

Functional analysis of P2's current suicide attempt

\begin{tabular}{|c|c|c|}
\hline Antecedents & Responses & Consequences \\
\hline $\begin{array}{l}\text { Historical } \\
\text { Aversive situations. } \\
\text { Psychological violence. }\end{array}$ & $\begin{array}{l}\text { Staying quiet, not expressing her } \\
\text { feelings. } \\
\text { Behavioral passivity. } \\
\text { Frequent crying. } \\
\text { Internalizing behavior:doesn't demonstrate } \\
\text { or talk about her feelings. }\end{array}$ & $\begin{array}{l}\text { Continuity of the psychological violence. } \\
\text { Behavioral deficits throughout the life history. } \\
\text { Lack of coping responses. }\end{array}$ \\
\hline $\begin{array}{l}\text { Current } \\
\text { Marital difficulties. } \\
\text { Marital fights: arguments, physical } \\
\text { aggressions by her husband and } \\
\text { psychological violence. } \\
\text { Privation of social contact. } \\
\text { Depression } \\
\text { Biological factors. } \\
\text { Environmental factors: lack of social } \\
\text { support, domestic violence, moving } \\
\text { from hometown - father's rule "The } \\
\text { woman must follow her husband". }\end{array}$ & $\begin{array}{l}\text { Behavioral passivity. } \\
\text { Feels fear, anguish, tightness in the chest. } \\
\text { Depressive behaviors: isolation, sadness, } \\
\text { frequent crying. }\end{array}$ & $\begin{array}{l}\text { Continuity of the fights. } \\
\text { He behavioral passivity reinforces her husband's aggressive } \\
\text { behavior. } \\
\text { Her husband gets angry with her depressive behavior, } \\
\text { shouting and arguing (positive punishment). }\end{array}$ \\
\hline $\begin{array}{l}\text { Immediate } \\
\text { Covert behavior and death wishes. } \\
\text { Thoughts: that nothing ever goes } \\
\text { well in her life. } \\
\text { Feelings of sadness. }\end{array}$ & $\begin{array}{l}\text { Current suicide attempt } \\
\text { Ingestion of medicine. }\end{array}$ & $\begin{array}{l}\text { The husband and the youngest daughter understood the } \\
\text { attempt and helped her (positive reinforcement - social } \\
\text { attention). } \\
\text { Was hospitalized (in an Intensive Care Unit) due to the } \\
\text { ingestion of medicine (positive punishment), and received } \\
\text { familiar support (positive reinforcement). }\end{array}$ \\
\hline
\end{tabular}

\section{Chart 3}

Functional analysis of P3's current suicide attempt

\begin{tabular}{|c|c|c|}
\hline Antecedents & Responses & Consequences \\
\hline $\begin{array}{l}\text { Historical } \\
\text { History of sexual and physical abuse } \\
\text { perpetrated by his aunt, in childhood. }\end{array}$ & $\begin{array}{l}\text { Aversive emotional state. Fear, shame } \\
\text { and anger. }\end{array}$ & $\begin{array}{l}\text { Lack of coping responses. } \\
\text { Continuity of the abuse throughout the childhood. The } \\
\text { people in his environment did not realize the abuse was } \\
\text { occurring (possible neglect). }\end{array}$ \\
\hline $\begin{array}{l}\text { Current } \\
\text { Memories of the abuse that occurred } \\
\text { in childhood. }\end{array}$ & $\begin{array}{l}\text { Cries, gets "revolted", feels anger because } \\
\text { suffered the abuse. } \\
\text { Discouragement, low self-esteem, self- } \\
\text { devaluation and excessive self-criticism. }\end{array}$ & $\begin{array}{l}\text { Death wishes - Expectation that death would cause the } \\
\text { aversive stimulation (suffering and memories of the abuse) } \\
\text { to cease. At the time, he did not exposes these behaviors; } \\
\text { the lack of environmental changes reinforced the idea that } \\
\text { his presence is indifferent. } \\
\text { The people in his environment did not pay attention to his } \\
\text { behavior (absence of reinforcement). }\end{array}$ \\
\hline $\begin{array}{l}\text { Immediate } \\
\text { Low environmental } \\
\text { responsiveness. } \\
\text { He was hearing voices that told him } \\
\text { he just bothers people, and that he } \\
\text { should end his life. } \\
\text { He was feeling sad. }\end{array}$ & $\begin{array}{l}\text { Current suicide attempt } \\
\text { Has used several methods (blade to cut } \\
\text { his wrists, stuck a pair of scissors in his } \\
\text { neck and stabbed himself). } \\
\text { Feeling of sadness, anger, anguish and } \\
\text { desire for an end to his suffer. }\end{array}$ & $\begin{array}{l}\text { His wife and children hold him after he carried out several } \\
\text { self-injurious behaviors. } \\
\text { He was taken to the general hospital. Received social } \\
\text { attention from his family (positive reinforcement). } \\
\text { Pain as a result of injuries (positive punishment). He exposes } \\
\text { the marks of the injuries, thus positive reinforcement is } \\
\text { possible, such as social attention. }\end{array}$ \\
\hline
\end{tabular}


10 I tried again; at 12, once more... and so it goes on". P3 reported that he suffered a lot and attributed this suffering to the abuse, perpetrated by his aunt, during his childhood; to the goals that he failed to achieve; and to his interpersonal difficulties.

It is possible to identify, in the report of P3, that his suicide attempts perform, at a high level, functions of escape and avoidance, because he reported that he wanted to die to end his suffering. It is also possible to identify, in the report of P3, some risk factors for suicide, such as a psychiatric disorder (diagnosed at the psychiatric hospital), suicidal ideation, and previous suicide attempts (the high level of potential lethality of the attempts should be noted), in addition to the lack of social support, since P3 had no friends (Chart 3).

The data obtained corroborate issues raised by other authors (Barrero, Guerra, Anaya \& Lopez, 1997; Bertolote \& Fleischmann, 2002b; Prieto \& Tavares, 2005; Turecki, 1999) in relation to suicide risk factors, such as the presence of suicidal ideation, previous suicide attempts, and the presence of a mental disorder. These factors were present in the life of all three participants. Furthermore, they allow the discussion of the factors, in each life history of these individuals, which contributed to the realization of this act, as well as the maintenance of this behavior. Considering that, in the three cases, the participants revealed a history of previous suicide attempts, the identification of the consequences of their attempts, through functional analysis, allows the formulation of hypotheses regarding the consequences of these attempts that will increase or decrease the probability of a recurrence of this behavior.

\section{Discussion}

In order to expand the epidemiological profile of suicide, quantitative studies are being published each year, emphasizing the risk factors (Barrero et al., 1997; Botega et al., 2009; Hesketh \& Castro, 1978; Kuo, Gallo \& Tien, 2001; Mello-Santos, Bertolote \&Wang, 2005; Nápoles, Sorí, Concepción \& Garcia, 1998). Nevertheless, little is known about how these risk factors are related to suicidal behavior, considering the life history of these individuals, as well as the context in which they are included

216 (Hjelmeland \& Knizek, 2010).
The realization of the functional analysis with the reported cases allowed the formulation of hypotheses about the function of these suicide attempts, according to the life history of each participant. A common characteristic to all of them was the presence of suicide risk factors, which can be considered as antecedents of the attempt. One of these factors was the report about the diagnosis of mental disorders prior to the current attempt (P1: bipolar disorder, P2: depression, and P3: bipolar disorder and depression). Studies concerning suicide and suicide attempt risk factors highlight the existence of a high correlation between these behaviors and the diagnosis of a psychiatric disorder (Prieto \& Tavares, 2005). According to the $\mathrm{WHO}$, in approximately $90 \%$ of suicide cases there was the presence of a mental disorder, the most frequent being the mood disorders, schizophrenia, personality disorders and substance-related disorders, with the individual possibly having been diagnosed with more than one disorder (Bertolote \& Fleischmann, 2002b; Pietro \&Tavares, 2005). Other risk factors present in the life of all three participants were suicidal ideation and previous suicide attempts. According to Botega, Barros, Oliveira, Dalgalarrondo and Marín-León (2005), it is possible to perceive a correlation between suicidal ideation and previous suicide attempts (Barrero et al., 1997; Prieto \& Tavares, 2005; Turecki, 1999). The occurrence of one or more previous suicide attempts is the main risk factor for suicide (Botega et al., 2005; Botega et al., 2009; Prieto \&Tavares, 2005; Suominen et al., 2004), with the estimate that $12 \%$ to $15 \%$ of survivors of suicide attempts go on to commit suicide (Meleiro \& Teng, 2004; Suominen et al., 2004) - and that this number may increase to $40 \%$ (Nápoles et al., 1998).

A history of physical, psychological or sexual violence also has a great influence as a risk factor for suicide (Meleiro \& Teng, 2004). In the case of sexual violence, identified in the life histories of P1 and P3, it can affect the development of children and adolescents in several ways, being considered a risk factor for the development of psychopathologies (Habigzang, Koller, Azevedo \& Machado, 2005), as well as for future suicide attempts (Brodsky et al., 2001; Dube et al., 2001; Johnson et al., 2002; Meleiro \& Teng, 2004; Turecki, 1999; Wilde et al., 1992). In the cases of $P 1$ and $P 3$, the suicide attempts began from the occurrence of the first abuse or abuse attempt, both in childhood. The abuse was reported as 
an important historical antecedent for the establishment of the suicidal ideation and subsequent suicide attempts.

Through the reports of the participants of this study, it can be inferred that they were in situations of social attention deprivation (especially from their families) during the period prior to the suicide attempts. According to Sidman (2001, p.133) "The sympathy that becomes available only after 'unsuccessful' suicides encourages further probable attempts". Thereby, the behavior of attempting suicide remains due to the positive reinforcing consequences (social attention of the family). According to Skinner (1953/2005, p.143) "A given act of deprivation usually increases the strength of many kinds of behavior simultaneously". In this way, it can be concluded that, at the time that the individuals were deprived of social attention, other types of behavior were probably started, and suicide attempts were effectively reinforced. Therefore, the double effect of social attention in suicide attempts becomes evident. At the same time that it protects the life of the individual (because the family may be engaged in helping or in contention behavior toward the individual in risk) it can also positively reinforce the attempt (as the only manner for the individual to obtain this reinforcement). In relation to this topic, Sidman (2001, p.133) states that:

If we follow the practice-pattern of Behavior Analysis, identifying what really succeeded after the attempts of self-destruction, it is probable that we will find the suicidal person becoming an object of attention and caring, the receiver of attention and sympathy. Guilt softens harsh voices, looses restrictions and replaces threats with promises of help.

However, some time after the suicide attempts, the environment again becomes coercive, and, as the previous attempt produced reinforcement, the individual may try to end his own life once more (Sidman, 2001). It is also important to consider that, each time, the environment requires responses closer to the final behavior - in this case, suicide "The environment gradually responds with a requirement for a higher intensity suicide attempt to elicit the same response" (Sidman, p.213). That is, it is necessary that the individual increase the potential lethality of the attempts to gain reinforcement (Banaco, 2001), which becomes evident from the report of P3's suicide attempts, who used more lethal methods in each subsequent attempt.
Based on the reports of the participants, it was established that the suicide attempt presents avoidance and escape functions from the aversive situations experienced by them. Considering that the participants reported a repertoire of problem-solving deficits, they started performing escape and avoidance behaviors, in order to cease or avoid further contact with the aversive stimuli present in their lives.

As is the case for all behavior, the suicide attempt is selected due to its consequences. Thus, it becomes essential to functionally analyze this behavior, in order to reflect on interventions in these reinforcement contingencies. Furthermore, it is necessary to offer guidance to the family and friends of the patient to enable appropriate management of the situation.

It is noteworthy that certain factors may have brought limitations to this study. First, the sample consisted exclusively of patients admitted to a psychiatric institution due to suicide attempts, and all the participants had previously received a mental disorder diagnosis. For a deeper analysis of all the cases, further studies could carry out interviews with the family of the participants, enabling a broader comprehension of the contingencies involved in the cases.

\section{Final Considerations}

The results of this study evidenced the presence of several risk factors for suicide present in the life history of the participants, as well as the presence of reinforcing consequences of the attempt. It demonstrates the tendency of such behavior to remain throughout life if there is no intervention. From a thorough comprehension of the factors related to the suicide attempts of each individual in particular, more effective strategies can be developed for each case. Therefore, it becomes extremely necessity to undertake more qualitative studies in the area of suicide, which can complement the various quantitative studies that are realized every year.

\section{References}

Banaco, R. A. (2001). Um levantamento de fatores que podem induzir ao suicídio. In H. J. Guilhardi, M. B. B. P. Madi, P. P. Queiroz \& M. A. Scoz (Orgs.), Sobre comportamento e cognição (pp.210-217). São Paulo: Esetec. 
Barrero, S. P., Guerra, L. A. R., Anaya, T. P., \& López, R. C. (1997). Factores de riesgo suicida en adultos. Revista Cubana de Medicina General Integral, 13(1), 7-11.

Bertolote, J. M., \& Fleischmann, A. (2002a). A global perspective in the epidemiology of suicide. Suicidologi, 7(2). Retrieved October 2, 2009, from <http://iaspinfo/pdf/ papers/Bertolotepdf>.

Bertolote, J. M., \& Fleischmann, A. (2002b). Suicide and psychiatric diagnosis: A worldwide perspective. World Psychiatry, 1(3), 181-185.

Botega, N. J., Marín-León, L., Oliveira, H. B., Barros, M. B. A., Silva, V. F., \& Dalgalarrondo, P. (2009). Prevalência de ideação, plano e tentativa de suicídio: um inquérito de base populacional em Campinas, São Paulo, Brasil. Cadernos de Saúde Pública, 25(12), 2632-2638.

Botega, N. J., Barros, M. B. A., Oliveira, H. B., Dalgalarrondo, P., \& Marín-León, L. (2005). Suicidal behavior in the community: Prevalence and factors associated with suicidal ideation. Revista Brasileira de Psiquiatria, 27(1), 45-53.

Brodsky, B. S., Oquendo, M., Ellis, S. P., Haas, G., Malone, K. M., \& Mann, J. J. (2001). The relationship of childhood abuse to impulsivity and suicidal behavior in adults with major depression. American Journal Psychiatry, 158(1), 1871-1877.

Dalgalarrondo, P. (2000). Psicopatologia e semiologia dos transtornos mentais. Porto Alegre: Artmed.

Dube, S. R., Anda, R. F., Felitti, V. J., Chapman, D. P., Williamson, D. F., \& Giles, W. H. (2001). Childhood abuse, household dysfunction, and the risk of attempted suicide throughout the life span. The Journal of the American Medical Association, 286(24), 3089-3096.

Durkheim, E. (1951). Suicide: A study in sociology. New York: The Free Press. (Original worky published 1897).

Fleischmann, A. (2009). Suicide prevention in different cultures. In World Health Organization. World suicide prevention day. Retrieved March 18, 2010, from <http:// www.who.int/mental_health/prevention/suicide/wspd_ 2009_statementpdf>.

Habigzang, L. F., Koller, S. H., Azevedo, G. A., \& Machado, P. $X$. (2005). Abuso sexual infantil e dinâmica familiar: aspectos observados em processos jurídicos. Psicologia: Teoria e Pesquisa, 21(3), 341-348.

Hesketh, J. L., \& Castro, A. G. (1978). Fatores correlacionados com a tentativa de suicídio. Revista Saúde Pública, 12, 138-146.

Hjelmeland, H., \& Knizek, B. L. (2010). Why we need qualitative research in suicidology. Suicide and LifeThreatening Behavior, 40(1), 74-80.

Jacobs, D. G., Baldessarini, R. J., Conwell, Y., Fawcett, J. A., Horton, L., Meltzer, H., et al. (2003). Practice guideline for the assessment and treatment of patients with suicidal behaviors. American Psychiatric Association, 160(11 Suppl.), 1-60. Retrieved May 15,2011,from <http://polsilver chaircom/ pracGuide/PracticePDFs/SuicidalBehavior_ Inactivated_04-16-09pdf>.

Johnson, J. G., Cohen, P., Gould, M. S., Kasen, S., Brown, J., \& Brook, J. S. (2002). Childhood adversities, interpersonal difficulties, and risk for suicide attempts during late adolescence and early adulthood. Archive of General Psychiatry, 59(8), 741-749.
Kuo, W. H., Gallo, J. J., \& Tien, A. Y. (2001). Incidence of suicide ideation and attempts in adults: The 13-year follow-up of a community sample in Baltimore, Maryland. Psychological Medicine, 31(7), 1181-1191.

Mann, J. J., Waternaux, C., Haas, G. L., \& Malone, K. M. (1999). Toward a clinical model of suicidal behavior in psychiatric patients. American Journal of Psychiatry, 156, 181-189.

Matos, M. A. (1999). Análise funcional do comportamento. Estudos de Psicologia (Campinas), 16(3), 8-18.

Meleiro, A. M. A. S., \& Bahls, S. (2004). O comportamento suicida. In A. M. A. S. Meleiro, C. T. Teng \& Y. P. Wang (Orgs.), Suicídio: estudos fundamentais (pp.13-36). São Paulo: Segmento Farma.

Meleiro, A. M. A. S., Teng, C. T. (2004). Fatores de risco de suicídio. In A. M. A. S. Meleiro, C. T. Teng \& Y. P. Wang (Orgs.), Suicídio: estudos fundamentais (pp.109-132). São Paulo: Segmento Farma.

Mello-Santos, C., Bertolote, J. M., \& Wang, Y. P. (2005). Epidemiology of suicide in Brazil (1980-2000): Characterization of age and gender rates of suicide. Revista Brasileira de Psiquiatria, 27(2), 131-134.

Nápoles, L. A., Sorí, G. H., Concepción, D. A., \& García, T. C. (1998). Conducta suicida: factores de riesgo asociados. Revista Cubana de Medicina General Integral, 14(2), 122-126.

O'Carroll, P. W., Berman, A. L., Maris, R. W., Moscicki, E. K., Tanney, B. L., \& Silverman, M. M. (1996). Beyond the Tower of Babel: A nomenclature for suicidoloy. Suicide and Life-Threatening Behavior, 26(3), 237-252.

Oliveira, A., Amâncio, L., \& Sampaio, D. (2001). Arriscar morrer para sobreviver: olhar sobre o suicídio adolescente. Análise Psicológica, 4(19), 509-521.

Prieto, D., \& Tavares, M. (2005). Fatores de risco paro o suicídio e tentativa de suicídio: incidência, eventos estressores e transtornos mentais. Jornal Brasileiro de Psiquiatria, 54(2), 146-154.

Sidman, M. (2001). Coerção e suas implicações. Campinas: Livro Pleno.

Skinner, B. F. (2005). Science and human behavior. Cambridge: The B. F. Skinner Foundation. (Original work published 1953).

Suominem, K., Isometsä, E., Suokas, J., Haukka, J., Achte, K., \& Lönnqvist, J. (2004). Completed suicide after a suicide attempt: A 37-year follow-up study. The American Journal of Psychiatry, 161(3), 562-563.

Turecki, G. (1999). O suicídio e sua relação com o comportamento impulsivo agressivo. Revista Brasileira de Psiquiatria, 21(2), 18-22.

Wilde, E. J., Kienhorst, I. C., Diekstra, R. F., \& Wolters, W. H. (1992). The relationship between adolescent suicidal behavior and life events in childhood and adolescence American Journal of Psychiatry, 149(1), 45-51.

Received on: 16/12/11

Final version on: 24/12/12

Approved on: 2/3/12 